\title{
UNIVERSITYOF
}

FORWARD

THINKING

WESTMINSTER用

WestminsterResearch

http://www.westminster.ac.uk/westminsterresearch

Security through societal resilience: Contemporary challenges in the Anthropocene

Chandler, D.

This is an accepted manuscript of an article published by Taylor \& Francis in Contemporary Security Policy, DOI: 10.1080/13523260.2019.1659574.

The final definitive version is available online:

https://dx.doi.org/10.1080/13523260.2019.1659574

(C) 2019 Taylor \& Francis

The WestminsterResearch online digital archive at the University of Westminster aims to make the research output of the University available to a wider audience. Copyright and Moral Rights remain with the authors and/or copyright owners.

Whilst further distribution of specific materials from within this archive is forbidden, you may freely distribute the URL of WestminsterResearch: ((http://westminsterresearch.wmin.ac.uk/).

In case of abuse or copyright appearing without permission e-mail repository@westminster.ac.uk 
Security through societal resilience: Contemporary challenges in the Anthropocene

Author and affiliation

David Chandler ORCHID: 0000-0002-2766-7169

School of Social Sciences, University of Westminster, London, UK

\title{
Correspondence details
}

David Chandler

School of Social Sciences, University of Westminster, 32-38 Wells Street, London, W1T 3UW.d.chandler@wmin.ac.uk

Disclosure statement: No potential conflict of interest was reported by the author.

Funding information: This research was supported by a visiting senior research scholarship at the Faculty of Social Sciences, Charles University, Prague, October 2018 March 2019.

\section{Notes on contributor:}

David Chandler is Professor of International Relations at the University of Westminster, London. His recent monographs include Becoming Indigenous: Governing Imaginaries in the Anthropocene (with Julian Reid) (Rowman \& Littlefield, 2019), Ontopolitics in the Anthropocene: An Introduction to Mapping, Sensing and Hacking (Routledge, 2018), International Peacebuilding: The Twenty Years' Crisis, 1997-2017 (Palgrave, 2017), The Neoliberal Subject: Resilience, Adaptation and Vulnerability (with Julian Reid) (Rowman \& Littlefield, 2016), and Resilience: The Governance of Complexity (Routledge, 2014).

\begin{abstract}
The concept of societal resilience has rapidly spread throughout the policy world, driven by the desire to use systems theories and process understandings to develop new security approaches for coping, bouncing-back, and adaptive improvement in the face of shocks and disturbances. However, this article argues that under the auspices of the Anthropocene, the assumptions and goals of societal resilience become problematic. This is because external interventions often ignore feedback effects, meaning that attempts to resolve problems through focusing upon enabling and capacity-building can be seen as counterproductive "fire-fighting" rather than tackling causation. Even more "alternative" or "community-based" approaches, relying upon interventions to enable so-called "natural" processes, either through an emphasis on local and traditional knowledge or new monitoring technologies, constitute problems for resilience advocacy: firstly, the problem of unrecognized exploitation; and secondly, the problem of continuing to sacrifice others to maintain unsustainable Western modes of consumption and production.
\end{abstract}

\section{Key words}




\section{Societal Resilience, Anthropocene, Security, Adaptation, European Union, international intervention}

Many international organizations, such as the European Union, have now adopted resilience strategies across various policy areas, linked to the broadening of the concept of security from a narrow state-level or military concern to a much more encompassing conception of societal capacities for "bouncing back" and adapting in the face of shocks and disturbances (European Commission, 2019; Tocci, 2019; Joseph, 2018; Chandler, 2014). The concept of resilience is attractive to international policy actors as it enables collaboration across different institutional and policy silos, pragmatically addressing problems and vulnerabilities with an emphasis on societal rather than merely state capacities (Tocci, 2019). As Tocci (2019) outlines, "societal resilience" is a key component of contemporary, much more holistic, approaches to security thinking, which seek to maintain a normative drive towards constant progress through "innovation, coping, and learning."

Discourses of societal resilience (Tocci, 2019; see also Chandler, 2013) argue that a new, more "pragmatic" and "holistic," approach to security is called for because the complexity of contemporary problems undermines traditional forms of "top-down" or linear imaginaries of state-based security. They therefore emphasize the importance of societal work; enabling and capacity-building communities and systems held to be "vulnerable," "at risk," or "failing" and enhancing, developing or scaling-up endogenous, innate or inherent resources and productive capacities. In discourses of societal resilience, the problems, shocks and instabilities being responded to are always constructed as "inevitable," in a complex or "non-linear" world where life is much less predictable, highlighted by the growing prevalence of extreme weather events, environmental crises and the tipping points associated with catastrophic climate change. This framing constructs societal resilience as always a process of adapting to external or outside forces and resilience policy interventions then concern the societal or community capacities for internal or selforganization, deploying different technologies and approaches to change, learn and adapt so as to enable social progress towards the liberal normative goals of "peace, rights, and development" (Tocci, 2019).

The Anthropocene, however, appears to disrupt the spatial and temporal imaginaries of security through societal resilience. "Coping," "adapting," and "recovering" are fine if the problem is external to the systems and processes concerned, but not if these systems themselves are part of the problem. In effect, the Anthropocene multiplies the interconnections and feedback, which discourses of resilience and complexity begin to recognize, questioning both the construction of the problem and the viability of the potential solutions, which are posited as key to international policy programs of resilience.

The argument of this article is that although the concept of societal resilience, informing the 2016 European Union' Global Strategy and other international policy documents, recognizes complexity as a challenge to contemporary security approaches, the Anthropocene problematizes the understanding of societal resilience as a security solution. This is for two reasons, firstly, the complexity of unseen or unrecognized policyfeedback is rarely framed to take into account the structural causes of resource depletion and social and economic marginalization, which makes communities and societies more vulnerable to shocks and disturbances (Neyrat, 2019; Whyte, 2019). Secondly, as a 
consequence of this framing, the policy interventions, based upon enabling and capacitybuilding for "societal resilience" often tend to impose the costs of adaptation upon those who are already in a marginal position, attempting to tackle the effects of crises and shocks but never the structural causes (Moore, 2019; Chandler \& Reid, 2019; Danowski \& Viveiros de Castro, 2016).

The claims made above are substantiated through the two sections of this article. The first section provides a brief introduction to the concept of the Anthropocene and its disruption of the assumptions, which ground policy approaches to societal resilience. It then draws out how this disruption works by moving beyond current policy articulations of complexity, which seek to "defer" or evade underlying problems rather than to address them. This artificiality is sometimes expressed as a problem of technical, bureaucratic, depoliticized or "top-down" approaches which seek to achieve short-term solutions or to paper-over the cracks. Then follows a second section dealing with "alternative" approaches to societal resilience, which seek to be more sensitive and responsive to feedback, these are divided between those that seek to develop a deeper engagement with local, community and indigenous forms of knowledge and those which seek to develop societal resilience though the application, at local and community scales, of new technologies such as satellite mapping and micro-level sensing. In conclusion, I argue that these alternative framings merely highlight the limits of programs of societal resilience in the face of Anthropocene understandings that "fire-fighting," the effects or consequences of climate change and legacies of capitalist and colonial modes of being, merely reproduces the hierarchies and forms of understanding which drive these problems in the first place.

\section{The Anthropocene and complexity}

The Anthropocene, initially a geological concept, claims that human actions have deeply affected and altered geologic processes, destabilizing earlier Holocene conditions of stability (Crutzen \& Stoermer, 2000; Stockholm Resilience Centre, n.d.). Thus, we are threatened with catastrophic climate change not as some sort of "external" threat to our modernist "internal" narratives of "peace, rights, and development" but precisely because our "internal" understandings of humanity as somehow separate to, or apart from, the nonhuman world were false. This attention to a new epoch in which humanity appears to have impacted the earth in ways which mean that natural processes can no longer be separated from historical, social, economic, and political effects has powerfully challenged the modernist understanding of the nature/culture divide, separating social and natural science, destabilizing the assumptions of both. Nature can no longer be understood as operating on fixed or natural laws, while politics and culture can no longer be understood as operating in a separate sphere of autonomy and freedom (Latour, 2013; Stengers, 2015; Chandler, 2018).

The end of the separations assumed by modernist or "linear" frameworks of policy governance is important to emphasize because it is precisely this aspect which makes the world more "complex" and less predictable: Our actions have unexpected and non-linear consequences or side-effects. For Anthropocene thinking, this complexity of inter-relation and interaction, means that it would be a mistake to view problems or "shocks" as merely external: something that social, economic or ecological systems need to recover or "bounce-back" from. As long as policy-makers and theorists presumed a modernist "world" external to us and amenable to governing and policy interventions, security approaches to societal resilience could still maintain normative goals of progress toward greater 
sustainability and adaptive capabilities, learning from disasters-even reimagining catastrophes as "emancipatory" (Beck, 2015)-or as facilitating new forms of self-growth and improved systems of self-management, "bouncing-forward" with what the former President of the Rockefeller Foundation, Judith Rodin (2015), described as the "resilience dividend."

However, the Anthropocene is seen to disrupt these understandings by viewing "complexity" as a global condition that has been generated by human action, which has made the world more interdependent and interconnected but at the same time removed the distinctions and separations that enabled discourses of societal security and "bouncing back." In many ways, conceptualizations of the Anthropocene follow through on the promissory notes of the globalization discussions of the 1990s in drawing out the implications of relational and system-thinking, which hold that there is no longer an "inside" and an "outside" (for example, Beck, 1992). Constructions of "insides" are those of autonomous agency or actors, central to modernist framings of law and politics: Thus "individuals," "states," "minds," etc were conceived to be separate from the world of relations which constituted them, rather than as integral parts. Likewise, "outsides" were seen to be merely passive, bound by natural laws and processes and amenable to objective knowledge and regulatory control, thus "nature," the "environment"--"nonhumans"--were constructed as objects to be known by subjects. This division between "insides" and "outsides" enabled modernist imaginaries of "progress," "civilization," and "development," based on the intensification of these binary divisions.

The Anthropocene challenges the aspiration of international actors such as the European Union in their desire to place societal resilience at the center of broader security strategies because complex relations of interaction destabilize the idea of a separate "inside" (Ghosh, 2016; Bonneuil \& Fressoz, 2016; Tsing, 2015). So, while resilience-thinking has achieved nearly universal success in the policy-making world--suggesting new sensitivities to problems and rejecting "high-modernist" technocratic approaches, which depended upon universal "one-size-fits-all" solutions from on high--resilience is still a "modern" construction which assumes that problems are "external" and that we need to develop policy solutions to maintain and to enable our existing modes of being in the face of shocks and perturbations. "We" need to be more responsive and adaptable. "We" need to be sensitive to minor changes and to "tipping points." In short, that "we" are not the problem, but that "we" need to develop new approaches to preserve our modernist imaginaries of development and progress. It is precisely this framing that Anthropocene sensitivities bring into question.

One example of the limits of societal resilience-thinking comes from a group of Swedish ecology scientists linked with the Resilience Alliance (Stockholm Resilience Centre, 2014) and published in Ecosphere, the journal of the Ecological Society of America (Rist et al., 2014). These scientists argue that resilience-thinking has been slow to think through the implications of the Anthropocene and the hidden costs of "anthropogenic impacts on the environment." The problem of ignoring these hidden costs is highlighted in their conceptualisation of "coerced resilience," which they define as:

Resilience that is created as a result of anthropogenic inputs such as labour, energy and technology, rather than supplied by the ecological system itself. In the context of 
production systems, coercion of resilience enables the maintenance of high levels of production. (Rist et al., 2014, p. 3)

Rist et al. (2014) define "anthropogenic inputs" as the external "replacement of specific ecosystem processes by inputs of labor and manufactured capital (e.g., fossil fuel, technology, nutrients, pesticides and antibiotics)" (p. 73). Thus policy interventions for societal security, which depend upon the taking of resources, technologies and materials from elsewhere, merely intensify and redistribute or spread the problems. This is firstly, because the process is held to weaken and undermine "natural processes" of resilience and, secondly, because importing resources weakens other, external, ecosystems.

Anthropogenic inputs to strengthen societal resilience may make the problem worse by weakening rather than strengthening natural ecosystem sources of resilience. For Rist et al. (2014), this can be clearly seen in the shift to anthropogenic dependencies: With the development of intensive agriculture techniques over a thousand years ago; in forestry, which has moved to the industrial scale over the last few hundred years; and in fisheries, which became industrial after the Second World War (p. 4). Rist et al. (2014) argue that one of the key problems with external technical assistance for societal resilience is that it "masks" or hides the real costs of production through the import of external capital, namely in the form of technology and fossil fuel-based energy (p. 3). Thus, the problem of some resilience policy interventions to enable the normative goals of sustainable development and human progress is thereby their "artifice" or falsity. For Rist et al. this "falsity" is itself a key problem of coercive resilience, as it undermines the very feedback processes that complex adaptive systems require. In order to be productive, these systems:

... rely on the maintenance of local ecological processes to retain a wider range of options for unforeseen future requirements, and thereby provide clearer feedbacks regarding proximity to ecological thresholds than do production systems... which require significant anthropogenic inputs. (Rist et al. 2014, p. 4)

Thus international policy interventions to enable societal resilience may merely enable tipping points to be reached sooner. The addition of anthropogenic inputs "mask" the growing loss of natural ecological system resilience maintaining systems in "artificial" states, entirely dependent upon more and more external inputs:

This raises an apparent paradox, whereby highly modified production systems can, through anthropogenic efforts rather than ecological processes, mimic the response of resilient natural systems to a specified disturbance, in their capacity to return to predisturbance system states. (Rist et al., 2014, p. 6)

This is a dangerous situation as artificial or "coerced" forms of support for societal resilience hides the capacities of these systems to draw upon natural ecological processes (highlighted in discussions of recent declines of wild and domestic pollinators and the plants and other species which rely upon them) (Rist et al., 2014, p. 6). A striking example of the limits of forced or coerced resilience is provided by anthropologist Michael Taussig, 
in his recent work, Palma Africana, on the production of palm oil in Colombia. One of the unintended and ironic consequences of increasing societal reliance through anthropogenic inputs, for example, the development of mono-crops, such as "Hope of America" palm, is that although artificially designed to prevent the spread of insect predation it needs additional anthropogenic interventions to artificially inseminate it. Thus, production becomes increasingly artificial, requiring more and more inputs, despite being sold to communities as a wonderful technical solution for raising productivity:

I see these women inseminators hard at it in the lustrous photographs provided by the Colombian Palm Growers Association. One woman is kneeling by an adult palm with a plastic tube in her mouth blowing sperm into the tiny flowers. In another photo a darkskinned young woman wearing bright pink jeans and a coal black jacket and cap guides the inseminating tool in her right hand while with her left she pushes back the palm branches studded with fierce thorns. With a look of equally fierce concentration she guides her instrument into its target all because "Hope of America" can't get it up. One would hope for more from "Hope of $\quad$ America." (Taussig, 2018, p. 74)

In language, which very much follows the lines of Rist et al. (2014), Taussig (2018) writes that:

Once triggered, assemblages tend to proliferate and somersault, one leading to the next... Another assemblage concerns the larger framework of relevant political cliché and self-awareness as to such - namely, third world women of color ministering to the sexual requirements of an impotent masculine "Hope of America" designed to stall the plagues brought by the very act of mono-cropping. We could continue. Thus does the assemblage principle provoke movement, speed, and metamorphosis. This is the way of things as much as a way of thinking with things. (p. 75)

Thus policy interventions with the intention of building societal resilience, rather than halting or slowing down the process of environmental destruction and exhaustion, can in fact be seen as part of the problem rather than the solution. For Rist et al. (2014), "coerced" forms of intervention to promote societal resilience cascade system effects of resource depletion through increasing "cross-boundary interactions" spreading the problem globally. One example they provide is that of livestock production, initially dependent upon farm-based resources and recycling waste products. In today's globalized interdependent world there is a decoupling of these processes, farm waste leaches into the environment rather than being recycled and intensive food production elsewhere (like soybean or palm oil) depends on ever higher inputs of synthetic mineral fertilizers, while global transportation merely adds to the consumption and waste of resources (2014, pp. 67). Thus vulnerabilities cascade through systems of positive-feedback, magnifying and extending the crisis of sustainability.

In the Anthropocene, it appears that many attempts to start from "pragmatic" resilience "problem-solving" assumptions merely make the initial problem worse. This discrediting of practical solutions, which were previously seen as part and parcel of "sustainable development" and "progress," is due to the complex global relations of interaction and 
inter-relation which come to the fore in the Anthropocene. In the Anthropocene there is no "outside" from which to draw resources. Modernity--now recast as the development of anthropogenic forms of "cheating" nature--reaches its closure at a global scale, making international policy-making to enhance societal resilience actually the driver for the problems it attempts to address: "because continued inputs are largely dependent upon, and ultimately limited by globally finite resources, such as fossil-fuel energy and phosphorous" (Rist et al., 2014, p. 7). The Anthropocene thereby problematizes these forms of international assistance for societal resilience precisely through revealing the problem of "masking" the environmental implications, which the distances of time and space had previously concealed. High levels of production and the speed of "bounceback" through resilience approaches were not enabling adaptation to new conditions but quite the opposite: Merely working to "mask or camouflage the ecological signals of resilience losses and thus the true underlying constraints to production" (2014, p. 8).

Criticisms of policy interventions to support societal resilience for their artifice and lack of attention to the "true underlying constraints" are rapidly increasing. Resilience-thinking, rather than being constructed as an alternative to the "policy silos" of linear security approaches, is more likely to be seen as the last redoubt of eco-modernizers and of modernist dreams of technological and technocratic approaches which attempt to short-cut problems rather than to tackle them at source (for example, Schmidt, 2013; Tierney, 2015; Neyrat, 2019). In the radical architecture journal Places, Lizzie Yarina, provides a useful example, in her piece Your Sea Wall Won't Save You (Yarina, 2018). Drawing on research on the management of flood risks in Jakarta, Manila, Ho Chi Minh City and Bangkok, she argues that discourses of societal resilience seek to preserve the interests of global investors and manufacturing supply chains through enforcing technocratic and top-down solutions for unsustainable growth (Yarina, 2018):

Since the city [Bangkok, but it could just as well be Jakarta or elsewhere] occupies a flood plain, it will inevitably be inundated again; adding concrete just makes the problem worse. Bangkok is constantly fortifying against flood risk caused by its very existence, thus exemplifying Ulrich Beck's framing of a "risk society" in which modern humans are caught in a cycle of mitigating risks they themselves have created.

She advocates "critical" or "soft" approaches to resilience, based on the inclusion of communities rather than "hard systems" of infrastructure and top-down technological or technocratic interventions, arguing that solutions lie in scaling-up informal housing communities with local knowledge, rather than demolishing informal slums and relocating people elsewhere. Thus, not only do the technical or "pragmatic" resilience solutions to flood risk make the problems worse on their own terms, in displacing local people with local knowledge, they cascade the problem, through removing alternative or "natural" processes of resilience:

In decades past (and still today in some rural parts of the country) Thai people lived in "amphibious communities": for example, in "raft houses" which float upwards on stilts during floods, or in villages built on two levels where upper walkways and living quarters can be used during the rainy season. But those adaptive patterns are disappearing even as climate risk grows. (Yarina, 2018) 
Thus the difficulty facing policy-makers concerned with interventions to support societal resilience become clear, and we can see a growing consensus that resilience is far from unproblematic as a security approach. For the critics of societal resilience considered above, existing approaches are problematized but there is still hope that resilience can be done better. There is a promise that societal resilience can be practiced more inclusively, "naturally," in "bottom-up" or "non-anthropogenic" and less "artificial" ways. This promise will be put to the test in the following section which suggests that the implications of the Anthropocene need to followed through and that in doing so, even 'alternative' approaches to societal resilience can be understood as contributing to the problem rather than mitigating it.

\section{Alternative approaches to societal resilience}

The problem of enhancing societal resilience through non-artificial ways that maintain the sensitivity to feedback and side-effects required in a complex world, requires getting closer to the problem rather than evading it by concreting over it or adding new artificial dependencies. But how can policy interventions for societal resilience avoid the problems of increasing rather than decreasing dependencies? What would non-coerced or nonanthropogenic approaches to resilience look like? For resilience even to exist as a policy intervention-even to begin to "attempt to use natural processes to enhance system resilience" (Rist et al., 2014, p. 8)---would appear to assume at least some anthropogenic actions. As Rist et al. (2014, p. 8) advocate, often "techno-fixes" may be required in the short-term as part of the process of using and manipulating "natural processes."

In such cases where coerced resilience is desired, the impacts on supporting and recipient system resilience must be considered. We argue that the ultimate goal is to retain or enhance the provision of global production system resilience through bolstering natural supporting processes rather than an increased reliance on anthropogenic inputs. (Rist et al., 2014, p. 9)

The game is rather given away here. The problems vitiating this approach are clear in the quote above. Firstly, there is a clearly instrumental approach to "natural processes," which are to be harnessed to support the existing status quo, thus 'the ultimate goal' is to support "global production system resilience." This has come to the fore particularly in experiments in "rewilding" and new forms of environmental conservation, seeking to enhance and expand "ecosystem services," geo- and bio-engineering nature to be more efficient (see, for example, Lorimer, 2015). As Tsing (2017, p. 16) notes, these resilience imaginaries are all part of an 'ecomodernist' fantasy which ignores the feedback effects of the Anthropocene. Secondly, even if this could be achieved, "natural processes" would be further modified by anthropogenic manipulation: The mere need to intervene to "bolster" these allegedly "natural processes" would inevitably produce other unintended stresses and strains according to the logic of the authors' own arguments. As Neyerat (2019) argues, these forms of intervention for societal resilience: "can only mean one thing, and this is one of the leitmotifs of post-environmentalism: Intervene even more - in other words. 'Creating and re-creating [the Earth] again and again for as long as humans inhabit 
it'." (: p. 85). In the Anthropocene, arguments for the instrumental use of "nature" can only speed up the process of catastrophic collapse.

The difficulties facing advocates of societal resilience are starkly clear in the examination of the alternative imaginaries of "soft," "natural," "non-coerced," "community", or "critical" approaches to societal resilience. One deeply problematic aspect of "alternative" approaches to resilience in the time of the Anthropocene is that the costs and burdens of sustaining the security concerns of international institutions are inevitably borne by those least able to resist the requirements of power. Resilience cannot possibly be undertaken in "soft," "critical," or "community" ways without very clearly redistributing the burdens of risk and sacrifice. Even these approaches inevitably assume that there is a hidden or cost-free resource that can be used, whether this is understood to be found in "nature," in "informal," "indigenous," or "non-modern" modes of being or in the use of new technologies for the self-monitoring and self-policing of communities already coping on the edge of poverty. These "alternative" approaches merely reproduce the problems of more "technical" or "topdown" coerced approaches in, firstly, ignoring the unintended or future costs and, secondly, and most importantly, assuming that modernist modes of consumption and production can continue practically unchanged.

Heuristically, the space in which "alternative" societal resilience approaches work can be clarified in terms of the need to operate through policy interventions which are "nonanthropogenic" in intent, i.e. which seek to intervene in social, economic and ecological processes with the goal of enabling or drawing out "natural" processes to enhance productivity and efficiency through tightening relational sensitivities and enabling better ways of sensing and responding to "natural signals" and "feedback." Thus resilience, as a set of policy interventions to enable adaptive capacities, always necessitates an instrumental or goal-directed set of sensitivities: Natural or immanent processes cannot be "enabled" by being left alone. Nature cannot ever be considered as somehow operating separately to social, economic and political processes. The starting assumption for resilience discourses is that we are now "after Nature" (Purdy, 2015) or "after ecology" (Morton, 2009; 2013; Latour, 2004). As Raygorodetsky argues, on behalf of the struggle to develop climate change adaptation and mitigation responses, even if we set aside half the planet as nature, as the Harvard biologist Wilson (2016) famously suggests:

This strict stance, however, does little to help get to the root of our destructive behaviour. Allowing development to destroy habitat in one area with a promise of "offsetting" this destruction by conserving another place actually perpetuates humankind's assault on the environment. It creates an illusion that as long as a portion of nature is put away and locked up in some sort of a park, we can rape and pillage the rest of the planet. (Raygorodetsky, 2017, p. 180)

As the Brazilian architectural theorist Tavares (2013, p. 234) argues, the Western idea of a pristine "nature" that can be preserved or kept away from human interaction has always been mythical. Even the Amazonian rain forests have been cultivated in sustainable ways by indigenous communities, thus "Amazonia's deep history is not natural, but human" (p. 234): "And this is perhaps the crucial paradox that the Anthropocene has brought to light: different regimes of power will produce different natures, for nature is not natural; it is the product of cultivation, and more frequently, of conflict" (p. 236). 
For alternative approaches to societal resilience the alternative to mono-crop agriculture, industrialized fisheries, sea walls and river "normalization" is never to "just let nature take its course." In discursive framings that are little different to neoliberal constructions of governance interventions that are "for the market"-designed to enable or to "free" the productive and organizational capacities of market forces, "nature" (like market forces) is never assumed to be "natural" (see Chandler, 2014). Nature, no longer separate to human systems, requires wise and active stewardship, like any other complex adaptive system. "Alternative" approaches to resilience are thereby not against technological applications and understandings but seek to apply them differently: to work with rather than against immanent productive processes, sensitive to feedback and unintended effects.

In alternative "community" approaches to societal resilience there are two dominant approaches to the problem of developing sensitivity to feedback and thus avoiding the dangers of "coerced" resilience. The first focuses upon the importance of local community knowledge and experience. In discourses of societal resilience two iconic figures of community emerge which embody the types of adaptive knowledge required, both of which are constructed as non-modern or non-universalist ways of knowing and of becoming sensitized to feedback effects, gained through lengthy experiences of coping with contexts of difficulty and trauma. These are the figures of the informal slum-dwelling community, attuned to environmental turbulence, and of indigenous communities, respectful of their relations to non-human others. Both these figures are imagined as resilient and selfsustaining communities, capable of coping, adapting to and 'bouncing back' from regular disturbances and disruptions.

There are a number of problems with these iconic figures of 'community' approaches to societal resilience. Although often well intentioned, it is difficult for Western agencies and activists to escape accusations that they are essentializing and romanticizing the life-styles and coping strategies of the marginalized communities they are offering up as role models for adaptive approaches. While there are many good arguments against the forced resettlement of informal communities, often to areas without suitable community support structures, the idea that slums should be scaled-up and enlarged so that informal ways of coping can be put at the disposal of the city dwellers, enabling them to continue undisturbed, seems to be exploitative rather than emancipatory (Castroni, 2009; Ogunlesi, 2016). A similar set of arguments would appear to undermine some of the claims made by environmental campaigners, seeking to ensure that indigenous communities maintain biodiversity on "our" behalf but only on the basis that they pledge themselves to maintain their ancestral beliefs and practices (Sissons, 2005; Chandler \& Reid, 2019).

Apart from being romanticizing and essentializing a lot of the claims made on behalf of these marginalized communities do not stand up to close examination. In many ways it is ironic that although the interlocutors from informal communities, that Western advocates draw upon, repeatedly state that they can no longer adapt in traditional ways--to changes in the river's path and momentum (Yarina, 2018; Chandler, 2017, p. 121) or that the climactic and seasonal signs that used to provide a guide to everyday life are now much more erratic and unreliable (Raygorodestsky, 2017, p. 59)--the "voices" of the people themselves are rarely heard in the rush to instrumentalize these survival strategies as "critical" alternatives. It seems clear that what is being drawn from these communities says much more about the desires of Western advocates and activists than about these communities themselves, many of which are adapting to change (including the impacts of 
climate change) in ways which have increasingly less and less relation to traditional or local knowledge-based practices (Raygorodestsky, 2017, p. 243).

Beyond the backward imaginaries of indigenous communities as "testing grounds" and "laboratories" (Raygorodestsky, 2017, p. 258) there is often a slightly more sophisticated Western agenda of understanding and scaling up adaptive capacities. The capacity that slum-dwelling and indigenous communities are imagined to have (and Western societies are imagined to lack) is the ability to see and respond to feedback effects. Alternative approaches to societal resilience thereby are increasingly moving beyond an understanding that local and traditional knowledge alone is key and towards scaling-up local knowledge through the assistance of new technologies, enabling communities to become resilient through being able to monitor and respond to changes in climactic and other conditions with greater speed and efficiency than waiting for government policy interventions.

Thus the second "alternative" approach to building societal resilience focuses less upon autonomous local knowledge capacities and more upon how new technological advances in algorithmic computation and distributive sensory capacities can enable local communities to be more self-sustaining. The use of technology, not as a "techno-fix" that artificially hides feedback effects but rather as one that enables them to be seen and responded to, is now central to "alternative" resilience imaginaries in the Anthropocene. The rolling out of Big Data and the Internet of Things approaches to local communities promises a level of responsiveness and sensitivity to environmental changes that was previously unimaginable. For its boosters, in the international development agencies and corporations, these approaches will transform small-scale agricultural production.

Even palm oil production receives a critical makeover. Rather than environmentally destructive industrial mono-cropping, small plot alternatives can be made economically viable if farmers sign up to digitally enhanced 'cloud-based' management systems, where farmers enable large scale data collection and sensory monitoring systems to be installed and so can monitor and minimize the use of chemicals and other anthropogenic resources as well as rapidly respond to drought, pests and disease--detecting problems even down to the level of specific trees and plots. Just as with Google and Amazon, sensitivities to feedback increases the more data is shared and drawn upon. As the founder of one agritech start-up states:

We specifically use... cloud storage (to store raw and processed imagery), cloud compute (to process huge amounts of data and extract insights), database storage and to serve our applications... to help farmers grow healthier crops is a perfect example of the way in which technology transforms traditional industries, leading to better livelihood conditions. Africa can be a harsh environment for farming. Crops are constantly under threat from problems such as disease, pests, and drought. Using the... cloud, we are bringing computation, data analytics, and other advanced technologies to help farmers grow healthier crops, despite the harsh conditions. (Cline, 2018)

Thus for some alternative approaches to societal resilience the answer lies in the application of new technologies which do not seek to artificially enhance economic processes but to make them more responsive to changes and feedback effects. It is for 
this reason that Big Data discourses often concern patterns and correlations rather than knowledge of causal processes (McKenna, 2016; Amoore \& Piotukh, 2016; Morozov, 2013; Mayer-Schonberger \& Cukier, 2013; Kitchin, 2014; Chandler, 2015). Big Data approaches seek to derive data from variable sources, linked through coding or datafication. According to a much-cited article by former Wired editor, Chris Anderson (2008), Big Data promises a world without the need for abstract theoretical models: "Correlation supersedes causation, and science can advance even without coherent models, unified theories, or really any mechanistic explanation at all." In these accounts, theories of causation can be dispensed with and massive and real-time data trails can stand in as reliable knowledge of the concrete relations on which policy and business decisions can be based.

According to the Rockefeller Foundation research group: "Large data collection and analysis may support communities by providing them with timely feedback loops on their immediate environment." (Crawford et al., 2013, p. 1) Rather than centralizing data produced through everyday interactions and applying algorithms that produce linear and reductive understandings, the aspiration of some Big Data approaches is that multiple data sources can enable individuals, households and societies to practice responsive and reflexive self-management in ways which were considered impossible before (for example, Marres, 2012; Halpern, 2014, pp. 242-243). In areas of societal resilience such as disaster risk reduction and disaster management the shift is already clear (de Coning, 2016; Ramalingam, 2013). Big Data is alleged to help empower precisely those that are most marginal and vulnerable at the moments of highest risk. Open information flows are thus held to contribute to the building of resilience by making communities aware of the risks and hazards they may encounter so that they can mobilize to protect themselves (Ahrens \& Rudolph, 2006, p. 217). This process is captured well by Meier (2013):

Thanks to [Information and Communication Technologies] ICTs, social media and Big Data... we can better measure our own resilience. Think of it as the Quantified Self movement applied to an entirely different scale, that of societies and cities. The point is that Big Data can provide us with more real-time feedback loops than ever before. And as scholars of complex systems know, feedback loops are critical for adaptation and change.

On this basis, international agencies, such as the World Bank, argue that it is possible for technological aids to enable communities to be more attentive to feedback effects and for societal resilience to have more of a positive impact for the UN's Sustainable Development Goals (World Bank, 2018; Chandler, 2016). One thing is clear, however, in this increasingly dominant perspective for dealing with risk, the world becomes much less amenable to transformative practices and experimentation. This limitation of possible alternatives is highlighted in Agamben's (2014) critique of resilience as the 'governance of effects'. He argues that whilst the governing of causes is the essence of politics, the governance of effects reverses the political process:

We should not neglect the philosophical implications of this reversal. It means an epoch-making transformation in the very idea of government, which overturns the traditional hierarchical relation between causes and effects. Since governing the causes is 
difficult and expensive, it is more safe and useful to try to govern the effects. (Agamben, 2014)

If societies or communities were able to govern effects, tackling problems in their emergence through rapid or real-time adaptation, then, in the Big Data imaginary, they would achieve societal resilience, able to cope autonomously with risks and threats without the need for external support or assistance. Big Data thus becomes the "Holy Grail" of neoliberal disaster management. This view of self-governing systems relies on cybernetic thinking on the basis of homeostatic feedback loops. The more responses are automatic, the more the detection of signs and signals are all that is required; no knowledge is necessary any more than a thermostat needs to know why temperature changes occur. The correlation between the sign or signal and the emergent problem is all that is necessary. The learning and adjustment of these correlations is the 'bouncing forward' aspect of a resilient society understood as a complex adaptive system; progress thus becomes reinterpreted as a process of managing stability better in the wake of additional potential risks and threats (for example, Rodin, 2015).

It is this alternative understanding of societal resilience that has driven the concern with information rather than with knowledge. Lazzarato (2014) has usefully highlighted that governance through signs displaces modernist views of subjectivity founded on universal linguistic, communicational and cognitive models: he understands this as "non-cognitive" capitalism:

Instead of a rational subject who controls information and his choices, homo economicus is a mere terminal of asignifying, symbolic, and signifying semiotics and of non-linguistic constituents which for the most part escape his awareness. We are not only well beyond the individualism and rationality of homo economicus, we have moved beyond "cognitive capitalism". (Lazzarato, 2014, pp. 99-100)

The removal of the knowing subject is key to the imaginary of the cybernetic world as one that is conflict-free, providing a cybernetic imaginary of a seamless interrelationship between the human, the machinic and the environment (Hayles, 1999, p. 288). Thus societal resilience as the desire to adaptively modulate around the equilibrium can be seen to erase the potential for human creativity (Halpern, 2014, p. 244).

Just as "coerced" resilience spread the problems of resource depletion and cascaded the lack of sustainability throughout the global system, it appears that "alternative" resilience approaches can easily spread "zones of sacrifice" (Yarina, 2018), scaling them up as some parts of the world are called upon to be resilient while other parts of the world "can rape and pillage the rest of the planet." While earlier ecological approaches advocated that parts of the world should literally be preserved to enable the rest of the world to go on as before, "alternative" approaches to societal resilience argue that local communities should be maintained in precarious, adaptive, informal or indigenous modes of life to act as frontline "responders" in the Anthropocene. While local communities, seen as the key actors in societal resilience, are often romanticized as coping in traditional and pre-modern ways, alternative approaches to societal resilience also present these communities as "testing grounds" or "laboratories" for more high tech coping mechanisms, based on new forms of computational power, seen to enable higher levels of responsiveness. In both cases 
"alternative" imaginaries seek to monitor, police and regulate the most marginal communities that are seen to need external policy intervention to scale-up their capacities for societal resilience so as to enable others to continue producing and consuming as before.

\section{Conclusion}

Societal resilience recognizes the limits of traditional security approaches in a complex and non-linear world. There are very good reasons for the adoption of resilience as part of a comprehensive security strategy, whether this is undertaken by the European Union, which has resilience as one of the core themes framing and cohering its 2016 Global Strategy or whether by other international institutions concerned with broadening an understanding of security in an unstable and unpredictable world. However, this article has drawn upon contemporary Anthropocene thinking to question whether societal resilience can achieve the goals claimed for it. In particular, it has sought to problematize the assumption that societal security can work on the basis of maintaining existing system states or enabling greater adaptive efficiencies. The reason that Anthropocene thinking disrupts these assumptions is that it understands them as dependent on an understanding that the problems being confronted are products of 'inevitable' shocks external to the system rather than ones generated precisely by the governance practices and modes of understanding of the international institutions seeking to address them.

While approaches of societal resilience focus on "bouncing back" and adapting to changing circumstances they can easily neglect that adaptation itself can be highly problematic. As has been analyzed above, what have been called "artificial" or "coercive" forms of adaption, relying on "anthropogenic" resources, can cascade problems through the system, precisely through increasing external dependencies and system rigidities making social systems less resilient and increasingly vulnerable. Alternative approaches to societal resilience can also be seen to evade the problem through focusing on the effects or consequences of climate change impacts in communities which are already vulnerable, precarious and marginalized, rather than the structural causes of these vulnerabilities, which are the products of modes of production and consumption in wealthier states and their historical (and on-going) relations of colonial and capitalist subordination (Todd, 2016; Moore, 2019; Whyte, 2019; Chandler \& Reid, 2019).

The article has further drawn attention to the problematic nature of alternative framings of societal resilience, which places the burden of adaption upon the most vulnerable and marginalized communities. Critical and community approaches often tend to romanticize and essentialize the coping strategies of marginal or indigenous communities, casting them as responsible for adapting to climate crises they played little role in creating, while taking the emphasis away from the need for changes in the modes of production and consumption in wealthier and more "resilient" Western states. It has also sought to problematize the assumption of many international institutions that new technological approaches of algorithmic sensing and computation will enable communities to cope on the edge of crisis through more rapid or "real-time" responses to climate and other changes, arguing that these framings naturalize precarious livelihoods rather than enabling more creative or transformative alternatives. In short, that discourses of societal resilience seek to evade the real nature of the problems posed by the Anthropocene and to redistribute costs and burdens increasingly upon those least able to resist them. Thus it 
has sought to highlight the existing inequalities, exclusions and blind spots of resiliencethinking. 


\section{Reference list}

Agamben, G. (2014). For a Theory of Destituent Power: Public lecture in Athens, 16.11.2013. Chronos, February. Retrieved from: http://www.chronosmag.eu/index.php/gagamben-for-a-theory-of-destituent- power.html

Ahrens, J. \& Rudolph, P. M. (2006). The Importance of Governance in Risk Reduction and Disaster Management. Journal of Contingencies and Crisis Management, 14, 207-220. DOI:10.1111/j.1468-5973.2006.00497.

Amoore, L. \& Piotukh, V. (eds) (2016). Algorithmic Life: Calculative Devices in the Age of Big Data. Abingdon: Routledge.

Anderson, C. (2008, June 23). The End of Theory: The Data Deluge Makes the Scientific Method Obsolete. Wired Magazine 16(7). Retrieved from: http://archive.wired.com/science/discoveries/magazine/16-07/pb_theory

Beck, U. (1992). Risk Society: Towards a New Modernity. London: Sage.

Beck, U. (2015). Emancipatory Catastrophism: What Does it Mean to Climate Change and Risk Society. Current Sociology, 63, 75-88. DOI: 10.1177/0011392114559951.

Bonneuil, C. and Fressoz, J.-B. (2016). The Shock of the Anthropocene. London: Verso. Castroni, M. (2009). Learning from the slums: literature and urban renewal. Arch Daily, 8 March. Retrieved from: http://www.archdaily.com/15271/learning-from-the-slums12literature-and-urban-renewal/

Chandler, D. (2013). Resilience and the Autotelic Subject: Towards a Critique of the Societalization of Security. International Political Sociology, 7, 210-226.

DOI:10.1111/ips.12018.

Chandler, D. (2014). Resilience: The Governance of Complexity. Abingdon: Routledge.

Chandler, D. (2015). A World without Causation: Big Data and the Coming of Age of Posthumanism. Millennium: Journal of International Studies, 43, 833-851. DOI: 10.1177/0305829815576817.

Chandler, D. (2016). How the World Learned to Stop Worrying and Love Failure: Big Data, Resilience and Emergent Causality. Millennium: Journal of International Studies, 44, 391410. DOI: $10.1177 / 0305829816636673$.

Chandler, D. (2017). Securing the Anthropocene? International Policy Experiments in Digital Hacktivism: A Case Study of Jakarta. Security Dialogue, 48, 113-130. DOI:10.1177/0967010616677714.

Chandler, D. (2018). Ontopolitics in the Anthropocene: An Introduction to Mapping, Sensing and Hacking. Abingdon: Routledge.

Chandler, D. \& Reid, J. (2019). Becoming Indigenous: Governing Imaginaries in the Anthropocene. London: Rowman \& Littlefield. 
Cline, T. (2018, October 30). Big Data And Smart Farmers For Africa's Agricultural Transformation. Forbes Africa. Retrieved from: https://www.forbesafrica.com/focus/2018/10/30/big-data-and-smart-farmers-for-africasagricultural-transformation/

Crawford, K., Faleiros, G., Luers, A., Meier, P., Perlich, C. and Thorp, J. (2013, October 24). Big Data, Communities and Ethical Resilience: A Framework for Action . Retrieved from: http://poptech.org/sys- tem/uploaded files/66/original/BellagioFramework.pdf

Crutzen P. J. \& Stoermer E (2000). The "Anthropocene". Global Change News, 41, 17-18.

Danowski, D. \& Viveiros de Castro, E. (2016). The Ends of the World. Cambridge: Polity.

de Coning, C. (2016). From peacebuilding to sustaining peace: Implications of complexity for resilience and sustainability. Resilience: International Policies, Practices and Discourses, 4, 166-181. DOI:10.1080/21693293.2016.1153773.

European Commission (2019). Fact Sheet: Resilience. February. Retrieved from: https://ec.europa.eu/echo/what/humanitarian-aid/resilience en

European Union (2016). Shared Vision, Common Action: A Stronger Europe, A Global Strategy for the European Union's Foreign And Security Policy. Brussels: European Action Service. Retrieved from: https://eeas.europa.eu/sites/eeas/files/eugs review web 0.pdf

Ghosh, A. (2016). The Great Derangement: Climate Change and the Unthinkable. Chicago, IL: University of Chicago Press.

Halpern, O. (2014). Beautiful Data: A History of Vision and Reason since 1945. Durham, NC: Duke University Press.

Hayles, K. (1999). How we Became Posthuman: Virtual Bodies in Cybernetics, Literature, and Informatics. Chicago, IL: University of Chicago Press.

Joseph, J. (2018). Varieties of Resilience. Cambridge: Cambridge University Press.

Kitchin, R. (2014). The Data Revolution: Big Data, Open Data, Data Infrastructures \& Their Consequences. London: Sage.

Latour, B. (2004). Politics of Nature: How to bring the Sciences into Democracy. Cambridge, MA: Harvard University Press.

Latour, B. (2013). Facing Gaia, Six Lectures on the Political Theology of Nature: Being the Gifford Lectures on Natural Religion, Edinburgh, 18th-28th of February 2013 (draft version 1-3-13). Retrieved from: https://macaulay.cuny.edu/eportfolios/wa kefield15/files/2015/01/LATOUR-GIFFORD-SIX-LECTURES 1.pdf

Lazzarato, M. (2014). Signs and Machines: Capitalism and the Production of Subjectivity. South Pasadena, CA: Semiotext(e). 
Lorimer, J. (2015). Wildlife in the Anthropocene: Conservation after Nature. Minneapolis, MI: University of Minnesota Press.

Marres, N. (2012). Material Participation: Technology, the Environment and Everyday Politics. Basingstoke: Palgrave Macmillan.

Mayer-Schonberger, V. \& Cukier, K. (2013). Big Data: A Revolution That Will Transform How We Live, Work and Think. London: John Murray.

McKenna, B. (2016, November 11). Analytics is not just about patterns in big data. Computer Weekly.com. Retrieved from: http://www.computerweekly.com/blog/DataMatters/Analytics-is-not-just-about- patterns-in-big-data

Meier, P. (2013, January 11). How to Create Resilience Through Big Data. iRevolutions. Retrieved from: https://irevolutions.org/2013/01/11/disaster-resilience-2-0/

Moore, J. (2019). Capitalocene and Planetary Justice. Maize 6, 49-54. Retrieved from: https://www.academia.edu/39776872/The Capitalocene and Planetary Justice?auto=do wnload

Morozov, E. (2013). To Save Everything Click Here: Technology, Solutionism and the Urge to Fix Problems that don't Exist. London: Allen Lane/Penguin.

Morton, T. (2009). Ecology without Nature: Rethinking Environmental Aesthetics. Cambridge, MA: Harvard University Press.

Morton, T. (2013). Hyperobjects: Philosophy and Ecology after the End of the World. Minneapolis, MI: University of Minnesota Press.

Neyrat, F. (2019). The Unconstructable Earth: An Ecology of Separation. New York, NY: Fordham University Press.

Ogunlesi, T. (2016, February 23). Inside Makoko: Danger and ingenuity in the world's biggest floating slum. Guardian. Retrieved from: http://www.theguardian.com/cities/2016/feb/23/makoko-lagos-danger-ingenuity-floatingslum

Purdy, J. (2015). After Nature: A Politics for the Anthropocene. Cambridge, MA: Harvard University Press.

Ramalingam, B. (2013). Aid on the Edge of Chaos. Oxford: Oxford University Press.

Raygorodetsky, G. (2017). The Archipelago of Hope: Wisdom and Resilience form the Edge of Climate Change. New York, NY: Pegasus Books.

Rodin, J. (2015). The Resilience Dividend: Managing disruption, avoiding disaster, and growing stronger in an unpredictable World. London: Profile Books. 
Schmidt, J. (2013). The empirical falsity of the human subject: new materialism, climate change and the shared critique of artifice. Resilience: International Policies, Practices and Discourses, 1, 174-192. DOI: 10.1080/21693293.2013.837241.

Sissons, J. (2005). First Peoples: Indigenous Cultures and their Futures. London: Reaktion Books.

Stengers, I. (2015). In Catastrophic Times: Resisting the Coming Barbarism. Paris: Open Humanities Press.

Stockholm Resilience Centre (n.d.) The nine planetary boundaries. Stockholm Resilience Centre. Retrieved from: https://www.stockholmresilience.org/research/planetaryboundaries/planetary-boundaries/about-the-research/the-nine-planetary-boundaries.html

Stockholm Resilience Centre (2014, November 29). The hidden cost of coerced resilience: Centre researchers look into forced resilience of intensive agriculture, forestry, fisheries and aquaculture systems. Stockholm Resilience Centre. Retrieved from: https://www.stockholmresilience.org/research/research-news/2014-11-29-the-hidden-costof-coerced-resilience.html

Taussing, M. (2018). Palma Africana. Chicago IL: University of Chicago Press.

Tavares, P. (2013). The Geological Imperative: On The Political Ecology of the Amazonia's Deep History. In E. Turpin (Ed.) Architecture in the Anthropocene: Encounters among Design, Deep Time, Science and Philosophy (pp. 207-239). Ann Arbor MI: Open Humanities Press.

Tierney, K. (2015). Resilience and the Neoliberal Project: Discourses, Critiques, PracticesAnd Katrina. American Behavioural Scientist, 59, 1327-1342. DOI:10.1177/0002764215591187.

Tocci, N. (2019). Resilience and the Role of the European Union in the World. Contemporary Security Policy. Advance online publication. DOI:10.1080/13523260.2019.1640342.

Todd, Z. (2016). An indigenous feminist's take on the ontological turn: 'Ontology' is just another word for colonialism. Journal of Historical Sociology, 29, 4-22. DOI: 10.1111/johs.12124.

Tsing, A. L. (2015). The Mushroom at the End of the World: On the Possibility of Life in Capitalist Ruins. Princeton, NJ: Princeton University Press.

Tsing, A. L. (2017). The Buck, the Bull, and the Dream of the Stag: Some unexpected weeds of the Anthropocene. Suomen Anthropologi, 42, 3-21. DOI: 65084.

Whyte, K. (2019). Way Beyond the Lifeboat: An Indigenous Allegory of Climate Justice. In K.-K. Bhavnani, J. Foran, P.A. Kurian and D. Munshi (Eds.) Climate Futures: Reimagining Global Climate Justice. University of California Press. Retrieved from: https://papers.ssrn.com/sol3/papers.cfm?abstract id=3003946 
Wilson, E. O. (2016). Half-Earth: Our Planet's Fight for Life. New York: Liverlight Publishing Corporation.

World Bank (2018). Machine Learning for Disaster Risk Management: A guidance note on how machine learning can be used for disaster risk management, including key definitions, case studies, and practical considerations for implementation. Washington, DC: author. 